\title{
Moving Across Borders: Brain drain or brain gain? A comparative study in Czechia and Germany
}

\author{
Alice Reissová ${ }^{\circledR}$ - Jana Šimsová ${ }^{1}$ - Ralph Sonntag ${ }^{2}$ \\ ${ }^{1}$ Faculty of Social and Economic studies, J. E. Purkyně University in Ústí nad Labem, Czechia. \\ ${ }^{2}$ Faculty of Business Administration, University of Applied Sciences Dresden, Germany \\ $\bowtie$ alice.reissova@ujep.cz
}

\begin{abstract}
The continuous drain of young university graduates leaving the country poses the threat of considerable loss, both economic and social. On the other hand, temporary labour migration can bring positive effects (experience, foreign know how). The objective of the article was to identify the attitude of German and Czech university undergraduates to labour migration and to explore the motivation factors that play a role in their decision-making. The research sample consisted of students of economics who study at regional universities in North Bohemia and neighbouring German Saxony. It was established that German students declare a greater interest in working abroad, but they tend to prefer temporary labour migration, while Czech students think more about permanently moving abroad, provided they are considering leaving for another country. Logistic forward stepwise regression was selected to establish significant explaining variables. Surprisingly, "higher salary" did not figure in the created models as an explaining variable in a single case. The amount of salary is an important motivation factor (both for Czech and German students), however, it is not the main factor which influences their decision to go abroad. The explaining variables "I want to live in a different country" and "the opportunity to gain international work experience" were shown in both cases. Governments as well as regional authorities should pay attention to the reasons why qualified workers decide on labour migration and they should pay due care to establishing why qualified workers want to live in a different country. Temporary labour migration should be encouraged and, at the same time, such conditions should be created to motivate highly qualified workers to return home.
\end{abstract}

\section{Highlights for public administration, management and planning:}

- The departure of young people with a university degree abroad represents considerable not only economic but also social losses.

- Temporary labour migration, however, can bring positive effects (experience, foreign know-how). German students declare interest in temporary labour migration, while Czech students prefer permanent migration.

- The salary is an important motivational factor (for both Czech and German students), but it is not the main factor that influences the decision to move abroad.

- Governments, as well as regional authorities, should pay attention to the reasons that lead qualified workers to decide for labour migration and to look closely at answers to why young people want to live in another country.

- Temporary labour migration should be supported by both government and regional authorities. In contrast, conditions should be created to eliminate permanent labour migration.

Keywords

Brain drain Permanent migration, Temporary migration, Motivation factors,

North Bohemia Saxony

Received:

27 June 2020

Received in revised form: 20 December 2020

Accepted:

17 February 2021 


\section{Introduction}

Migration is generally understood as a change of permanent residence. In the case of internal migration, it is a change of permanent residence beyond the borders of a certain administrative unit (e. g. municipality), while in the case of external migration people move across national boundaries. External migration of educated and talented persons is often denoted as "brain drain". International migration heavily impacts both emigration and immigration countries. Among the negative consequences of international migration are a decrease in the growth potential of the country of origin, loss of taxes in the country of origin after migrants leave the country, and a decrease in the capacity of the country to adopt new technologies. On the other hand, according to Bălan and Olteanu (2017), beneficial effects might also be observed in the form of payments of money (transferred to the country - remittances). In the case of economic migration, it is usually the movement of people from a less developed or performing economy to a more developed and better perform ing economy. However, it would be a mistake to think that brain drain affects less developed countries only. Both internal and external migration (brain drain) is also faced by large and strong economies, such as Germany (Busch \& Weigert 2010; Kaplan et al. 2016; von Proff et al. 2017), USA (Marx et al. 2015) or the United Kingdom (Faggian, Mccann \& Sheppard 2007). Many not only European countries are starting to perceive this phenomenon as a significant problem. The outflow of experts may represent a significant loss for a country, both at the structural (outflow of experts of a particular specialization, e.g., doctors, IT specialists) and demographic level (outflow of a large number of the young generation). One exception is so-called temporary migration, when people leave a country for another for a limited period. A foreign working visit usually increases their qualifications and they subsequently return to their home country, which thus acquires a highly skilled worker bringing foreign experience. Permanent labour migration in some countries is so urgent a problem that governments are preparing various horizontal measures to regulate labour migration (Lapshyna 2012).

This paper tries to establish whether university students consider moving to a different country upon completion of their studies where they would live and work, whether they intend to leave temporarily or permanently and what the most frequent rea- sons causing the brain drain are. University student populations showing identical features (age, field of study, public university) will be compared; they will differ in the country where they live and study, the different economy of the country and asymmetry of the labour markets (Germany and Czech Republic).

\section{Theoretical background}

Factors motiving people to move to a different country are denoted as push and pull factors. Push factors make an individual leave the country (e.g., low standard of living, war, etc.). On the other hand, pull factors attract individuals to the country (higher standard of living, opportunity of personal development, etc.). It is necessary to strictly distinguish between migration of highly qualified workers and massive migration of refugees from African and Eastern-European countries (Józsa \& Vinogradov 2017). While push factors matter more with refugees (war, pressing political situation, low standard of living), pull factors are more typical for labour migrants (higher standard of living, greater opportunities of personal and career development, etc.).

Over the last decades, the countries of Central and Eastern Europe have witnessed a significant increase in labour migration. In his study, Ionescu (2015) focused on the emigration of universityeducated individuals from six different Eastern European countries (Bulgaria, the Czech Republic, Hungary, Poland, Romania, and the Slovak Republic). He studied the emigration of citizens from these countries in the period 1980-2010. He found that emigration sharply increased upon the entry of the countries to the European Union. Among these countries, Romania and Poland are the most affected by the brain drain. Two factors significant in shaping emigration were identified using regression analysis. They are wages (influenced by GDP) and education expenditure (influenced by inflation). The increase in labour migration upon the entry of the Czech Republic to the EU is also referred to by, e.g., Vavrečková et al. (2002); however, Czech labour migration is significantly lower than the migration of Romanians, who most often head to Germany, Hungary, the USA, and Canada (Petroff 2016). In recent years, a number of studies dealing with brain drain were carried out in Romania (Dobrota \& Aceleanu 2006; Meeus 2013; Boncea 2015; Ailenei et al. 2015; Petroff 2016; Bălan \& Olteanu 2017; Panzaru \& Reisz 2017; Haller 2017). 
Poland also shows significant interest in this matter (Grabowski 2005; White 2010; Friberg 2012; Bielewska \& Jaskułowski 2017). More detailed research was performed by Józsa \& Vinogradov (2017) in Hungary. Using the Likert scale, they measured which motives have the most influence on labour migration. According to the results of the study, the strongest motivational factors are: better earning opportunities, vision of future, job opportunities, free life, improvement of language skills, career growth opportunities. Less weight was attributed to relationships created abroad and work during studies abroad. Extensive research into migration was also conducted in Slovakia. The following push factors were identified: lack of jobs, low standard of living and low wages. Among the pull factors attracting Slovaks are improvement of language skills, acquiring work experience and opportunities to travel. Economic motives were identified as the strongest. Countries where Slovaks want to go to most often are the United Kingdom, Austria, Germany, Switzerland and the USA (Spankova, Grencikova \& Kordos 2016). There are also studies dealing with labour migration of particular professions. Very often, they deal with the outflow of health professionals - doctors and nurses - abroad. The outflow of health professionals from the Czech Republic to Germany was discussed, e.g., by Dolejš et al. (2016). The main push factors influencing migration were identified as worse financial conditions (wages) and excessive workload and overtime in Czech hospitals.

It is clear from the text above that Germany is becoming a sought-after country for many migrants. This migration, however, is not one-sided as young and educated people leave Germany as well. Due to the fact that Germany is a large country, there are significant differences among regions in this area. Therefore, studies that focus on the interregional migration of university graduates, for example, to and from the Saxony region are emerging (Kaplan et al. 2016). The reasons why young graduates migrate from Germany are usually not related to economic conditions, but rather socio-economic variables play a role (Busch \& Weigert 2010).

It is very important whether the skilled workforce leaves the country of origin permanently or temporarily. While permanent outflow significantly weakens the economy of a country, temporary outflow may be very beneficial and positive. Therefore, in relation to labour migration, it is very important to ask whether the people leaving are planning to return home or whether they are leaving forever. Józsa and Vinogradov (2017) found that people migrating for permanent work are more moti- vated by higher wages than those who are planning temporary migration and want to return to their home country. Labrianidis and Vogiatzis (2013) who studied labour migration of Greeks in the times of the economic crisis believe that the "brains" will not return. Spankova et al. (2016) state that 27\% of Slovaks who leave want to stay permanently abroad and $35 \%$ of respondents intend to return home. It is necessary to point out that these are predictions which may not come true. Dolejš et al. (2016), who dealt with the topic of Czech health professionals leaving for Germany, state that only a small number of respondents stay in Germany (mainly those who get married there). For most of the respondents, it is temporary migration; most often, they return to the Czech Republic due to family reasons.

Countries which are already experiencing a strong outflow of skilled human capital try to create such conditions and programs to motivate their citizens to return to their home country. As examples we can mention Kazakhstan (Zhatkanbaeva, Zhatkanbaeva \& Zhatkanbaev 2012), Romania (Boncea 2015; Petroff 2016), Italy (Hussain 2015), Ukraine (Illiashenko \& Adamets 2017), Tajikistan (Mirzobobo 2017), Yemen (Muthanna \& Guoyuan 2018), and also China (Cai 2000) and many others. Some authors concentrate on the return policy of more countries, such as Lados (2013), who deals with migration matters in Central Europe, where he finds common characteristics, mainly among Hungarian and Polish migrants. He points out that unless Central European counties succeed in stabilizing macro-factors, the return of migrants might be uncertain. On the other hand, it was found that the return of migrants to their home country does not always have to be easy. Reiner and Radu (2012) focused on migrants returning to Central and Eastern Europe. He points out potential problems with active employability in the labour marking and job searching. They state that it is likely that rather than traditional employment some of them will seek self-employment.

\section{Methodology}

The objective of this paper was to find out whether the students consider leaving for abroad within their professional career and, if so, whether they intend to move permanently or migrate only temporarily. Another objective was also to identify the main motivation factors of labour migration. All aforementioned questions will be studied for German and Czech students and subsequently a com- 
parison and identification of differences will be carried out.

The research population comprised students of economic fields from a German and a Czech university. They were both regional public universities located geographically close to each other (in the range of tens of kilometres). In particular, they were Hochschule für Technik und Wirtschaft Dresden (hereinafter referred to as "HTWD") and the Faculty of Social and Economic studies of Jan Evangelista Purkyně University in Ústí nad Labem (hereinafter referred to as "FSE UJEP"). The research was conducted using the written questionnaire method. The substantive questions concerned the idea of their employment after graduation from school (I will be employed in my home country I will run a business - I will work abroad) and in case they consider going abroad, whether they expect to leave their country temporarily or permanently. For each of these items, the respondents answered on a scale: definitely yes, rather yes, rather no, and definitely no. They could also mark the options "I am already running a business", "I am already working" (see Table 2 and 3 ).

Furthermore, the questions focused on individual motives that may play a role in deciding on labour migration. Students evaluated individual motivation factors using a 7-grade Likert scale (with 1 meaning "definitely yes" and 7 "definitely not"). Answer coding was specularly reflected (i.e., 7, 6, 5, 4, $3,2,1)$. It means that the lower values of 1,2 , and 3 mean negative answers, while 5, 6, and 7 represent a different strength of positive answers.

Table 1 shows the factors for which students indicated how powerfully they would motivate them to leave for abroad on the Likert scale. Lower values of 1,2 , and 3 mean negative answers ( $1=$ low motivation), while 5, 6, and 7 represent different strengths of positive answers ( $7=$ high motivation).

Table 1 Summary of tested motivation factors

\begin{tabular}{ll}
\hline amot & Higher wages than in the home country \\
bmot & More favourable social, health and tax system \\
cmot & Opportunity to learn/improve a foreign language \\
dmot & Opportunity to acquire foreign experience \\
emot & $\begin{array}{l}\text { Better working conditions than } \\
\text { in the home country }\end{array}$ \\
fmot & $\begin{array}{l}\text { Better opportunities for career growth } \\
\text { than in the home country }\end{array}$ \\
gmot & $\begin{array}{l}\text { I want to live in a different country } \\
\text { It will be easier to find a job abroad }\end{array}$ \\
hmot & than in my home country \\
\hline
\end{tabular}

The questionnaire also included an open-ended question: "If you would like to work abroad, which country would you choose?" The respondents could answer this question freely in their own words. The answers were then categorized.

In Germany, the questionnaire was administrated in the German language; in the Czech Republic, in Czech. Students completed their questionnaires in classrooms during lessons (upon prior agreement with the respective teacher). The questionnaires were anonymous. After checking the correctness of data and eliminating incomplete or incorrectly completed questionnaires, 503 questionnaires were included in the population. There were 248 respondents from HTWD (Germany), of whom 110 were men and 138 women; there were 255 respondents from FSE UJEP (Czech Republic), of whom 85 were men and 170 women.

The data were processed using MS Excel, STATISTICA and SPSS; subsequently, statistical methods were applied: chi-square test of homogeneity, test of parameter matching of two binomial distributions, logistic forward stepwise regression, Hosmer and Lemeshow test. Logistic regression was chosen as this method makes it possible to identify the factors that lead to labour migration and also to evaluate the extent of their impact.

\section{Results}

\subsection{Labour migration prediction}

First of all, it was investigated what the students' work plans for the period of 3-5 years after their studies were. They were provided with the following options: "I will be employed", "I will run a business", "I will work abroad". Answers to this question are given in Table 2.

It clearly follows from the results that the German students' perspectives slightly differ from those of the Czech students. The German students show greater willingness to run businesses and also work abroad. It was also investigated whether the students would, in case of labour migration, consider a temporary stay or permanent emigration from their country. The results in Table 3 show that while the Germans think of temporary stay more often, the Czechs consider permanent emigration.

The homogeneity of the German and Czech student populations was tested using a chi-square test. With the question whether the students are willing to move temporarily and work abroad, the homogeneity of the German and Czech populations cannot be rejected ( $p$-value $=0.08586$ ). Although some differences in future plans were found, they are not statistically significant. 
Table 2 Students' plan (relative frequency)

\begin{tabular}{lrrrrrr}
\hline \multirow{2}{*}{ Answers } & \multicolumn{3}{c}{ Germans $(\mathrm{n}=248)$} & \multicolumn{3}{c}{ Czechs (n=255) } \\
& $\begin{array}{l}\text { I will be } \\
\text { employed }\end{array}$ & $\begin{array}{l}\text { I will run } \\
\text { a business }\end{array}$ & $\begin{array}{l}\text { I will work } \\
\text { abroad }\end{array}$ & $\begin{array}{l}\text { I will be } \\
\text { employed }\end{array}$ & $\begin{array}{l}\text { I will run } \\
\text { a business }\end{array}$ & $\begin{array}{l}\text { I will work } \\
\text { abroad }\end{array}$ \\
\hline Definitely not & 2 & 5 & 13 & 2 & 16 & 15 \\
Probably not & 16 & 41 & 50 & 8 & 53 & 61 \\
Probably yes & 65 & 42 & 31 & 38 & 24 & 22 \\
Definitely yes & 16 & 10 & 7 & 37 & 4 & 2 \\
I am already working/running a business & 1 & 2 & 0 & 14 & 3 & 0 \\
\hline Total (\%) & 100 & 100 & 100 & 100 & 100 & 100 \\
\hline
\end{tabular}

Results given in $\%$ are rounded to whole numbers

Table 3 Permanent versus temporary labour migration (relative frequency)

\begin{tabular}{lrrrr}
\hline \multirow{2}{*}{$\begin{array}{l}\text { Tabour } \\
\text { migration }\end{array}$} & Germans & Czechs & Germans & Czechs \\
\hline Definitely not & 13 & 14 & 33 & 11 \\
Probably not & 28 & 36 & 36 & 38 \\
Probably yes & 42 & 38 & 23 & 36 \\
Definitely yes & 18 & 11 & 8 & 14 \\
Total (\%) & 100 & 100 & 100 & 100 \\
\hline
\end{tabular}

Results given in $\%$ are rounded to whole numbers

Table 4 Proportions match test - willingness to move abroad temporarily or permanently

\begin{tabular}{lcccc}
\hline \multirow{2}{*}{ Labour migration } & \multicolumn{2}{c}{ Temporary } & \multicolumn{2}{c}{ Permanent } \\
& Germans & Czechs & Germans & Czechs \\
\hline $\begin{array}{l}\text { Relative frequency } \\
\text { of positive answers }\end{array}$ & 0.592742 & 0.498039 & 0.310484 & 0.501961 \\
p-values & $\mathrm{p}=0.0165$ & $\mathrm{p}=0.0000$ \\
\hline
\end{tabular}

For the question whether the students are willing to move abroad permanently, the $\mathrm{p}$-value found was 3.29483E-08. In this case, homogeneity of the populations was rejected. This means that for permanent labour migration, the German and Czech students have different preferences. It was also tested whether the proportions of German and Czech students giving positive answers to individual questions are the same. A one-sided alternative hypothesis was chosen. The results of the test are given in Table 4.

Table 4 shows that a proportion match of students in both student populations willing to move abroad temporarily or permanently was rejected. As far as willingness to move abroad temporarily is concerned, the proportion of the German students is statistically more significant than that of the Czech students. The German students declare statistically significantly greater willing- ness to move abroad temporarily, while the Czech students prefer permanent labour migration.

In case of leaving for abroad, in most cases, the German students would like to work in the United Kingdom and the USA, while the Czech students most often indicated Germany, the United Kingdom and the USA.

\subsection{Motivation factors leading to labour mi- gration of German students population}

It clearly follows from Table 5 that the highest value of the arithmetic average belongs to motivation factor d (Opportunity to acquire foreign experience). The lowest value is for motivation factor $h$ (it will be easier to find a job abroad than in Germany). Motivation factor d (Opportunity to acquire foreign experience) has the lowest variability of answers, which is highest for motivation factor $g$ (I want to live in a different country). The table also shows that the values of the arithmetic means of the motives a to $\mathrm{f}$ are relatively balanced.

Fig. 1 clearly illustrates that motivation factors (Higher wages than in Germany), c (Opportunity to learn/improve a foreign language), and d (Opportunity to acquire foreign experience) were scored 6 or 7 (high motivation) by $50 \%$ of the German students.

However, the most powerful motivation factors do not need to have the biggest impact on a positive decision about labour migration. To establish this impact, logistic regression was chosen. For the answers to the question "Would you ever like to work abroad?", positive and negative categories of answers were combined. This created a dichotomous variable. All motivation factors and the dichotomous variable of gender were included among the explanatory variables. To establish significant explanatory variables, logistic forward stepwise regression was chosen. For the German student population, there were only two statistically significant explanatory variables, i.e., motivation factor $\mathrm{g}$ 


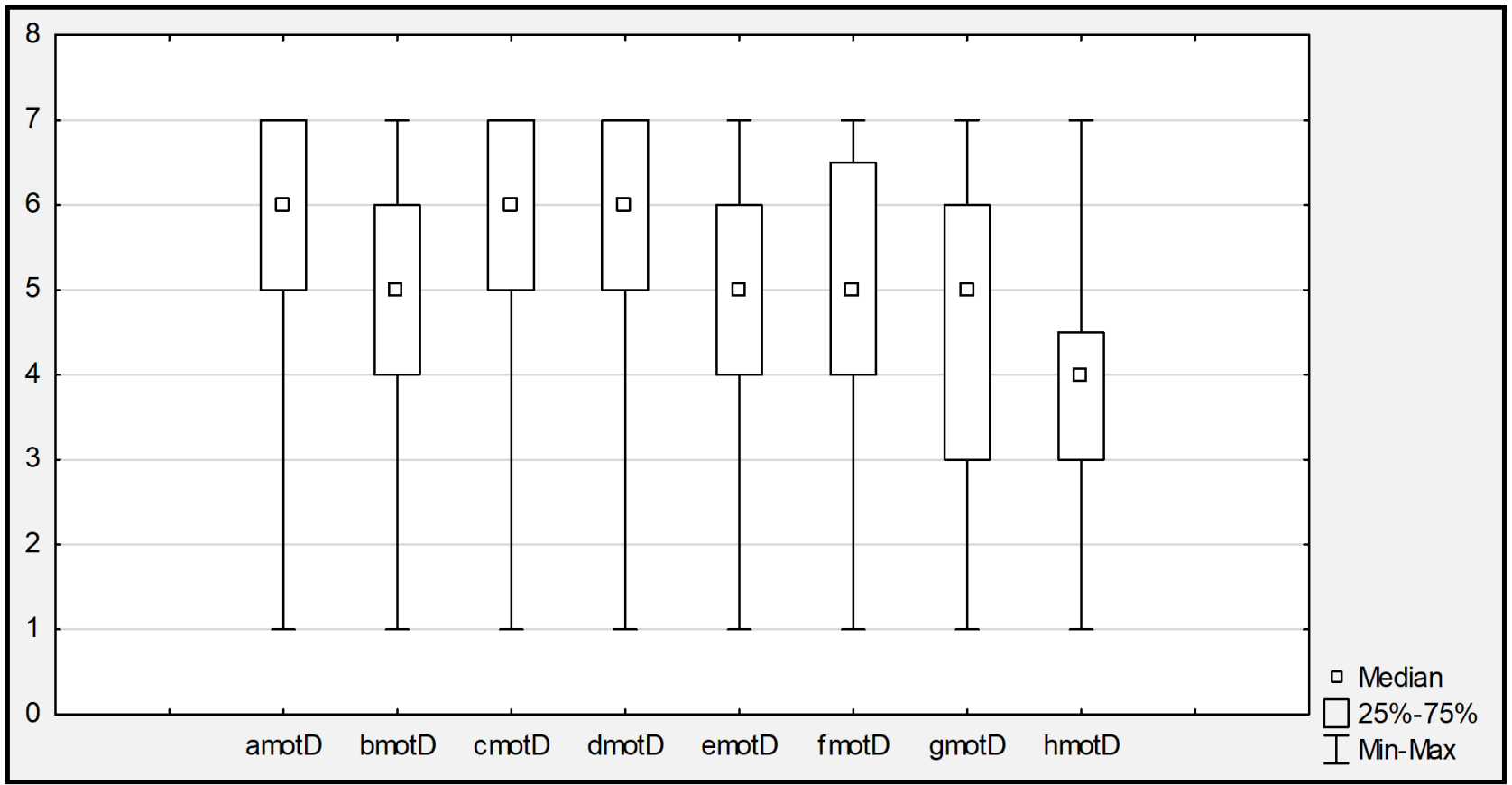

Fig. 1 Labour migration motivation factors - German student population.

Table 5 Descriptive statistics of individual motivation factors of German student population

\begin{tabular}{lrrrrrrrr}
\hline & amotD & bmotD & cmotD & dmotD & emotD & fmotD & gmotD & hmotD* \\
\hline Ar. Average & 5.4476 & 5.0081 & 5.5323 & 5.871 & 5.11694 & 5.2419 & 4.41936 & 3.7056 \\
Median & 6 & 5 & 6 & 6 & 5 & 5 & 5 & 4 \\
Modus & 7 & 6 & 7 & 7 & 5 & 5 & 6 & 4 \\
St. deviation & 1.4694 & 1.6272 & 1.5789 & 1.3938 & 1.5424 & 1.5579 & 1.91984 & 1.4306 \\
Variance & 2.1592 & 2.6477 & 2.4929 & 1.9428 & 2.37898 & 2.4271 & 3.68578 & 2.0466
\end{tabular}

The first row of the table always includes a letter denoting a motivation factor (see Tab. 5). Letter D denotes the German student population (for the Czech student population, "CZ" will be used).

(I want to live in a different country) and motivation factor $d$ (Opportunity to acquire foreign experience). The values of coefficients of individual explanatory variables in the model and their significance are given in Table 6.

Table 6 Model of logistic regression - German student population (Variables in the Equation)

\begin{tabular}{llrrrrrr}
\hline & & B & S.E. & Wald & df & Sig. & $\operatorname{Exp}(\mathrm{B})$ \\
Step $1^{\mathrm{a}}$ & GmotN & 0.754 & 0.097 & 60.32 & 1 & 0 & 2.125 \\
& Constant & -3.022 & 0.452 & 44.726 & 1 & 0 & 0.049 \\
Step 2 & bmotN & 0.338 & 0.148 & 5.207 & 1 & 0.022 & 1.402 \\
& GmotN & 0.664 & 0.103 & 41.3 & 1 & 0 & 1.942 \\
& Constant & -4.641 & 0.893 & 26.98 & 1 & 0 & 0.01 \\
\hline
\end{tabular}

${ }^{a}$ Variable(s) entered in step 1: GmotN.

bVariable(s) entered in step 2: DmotN.

It follows from the Wald statistics and their p-values in Tab. 6 that all coefficients in the model significantly differ from zero.
The model shows that the biggest impact on whether a student would like to leave to work abroad is based on motivation factor $g$ (I want to live in a different country). The likelihood that a student will ever be willing to leave to work abroad increases with each higher score on the Likert scale to 1.942 times. Motivation factor d (Opportunity to acquire foreign experience) has the second biggest impact. In this case, each increase by one score on the Likert scale towards absolute agreement increases the chance that a student will be willing to work abroad by 1.402 times. On the basis of this model, the likelihood that a student will ever want to work abroad can be estimated as follows:

$$
\pi=\frac{e^{-4.641+0.664 \cdot g m o t+0.338 \cdot d m o t}}{1-e^{-4.641+0.664 \cdot g m o t+0.338 \cdot d m o t}}
$$


Table 7 Classification table - Model Success Rate Calculation - Germany)

\begin{tabular}{llcrrr}
\hline & & \multicolumn{3}{c}{ Predicted } \\
& Observed & & \multicolumn{2}{l}{ Work Abroad } & Percentage \\
& & & 0 & 1 & Correct \\
\hline \multirow{3}{*}{ Step 1 } & Work Abroad & 0 & 81 & 27 & 75 \\
& & 1 & 29 & 111 & 79.3 \\
& Overall Percentage & & & 77.4 \\
Step 2 & Work Abroad & 0 & 71 & 37 & 65.7 \\
& Overall Percentage & 1 & 20 & 120 & 85.7 \\
& & & & \\
\hline
\end{tabular}

Table 8 Descriptive statistics of individual motivation factors of the Czech student population)

\begin{tabular}{lrrrrrrrr}
\hline & amotCz & bmotCz & cmotCz & dmotCz & emotCz & fmotCz & gmotCz & hmotCz \\
\hline Ar. Average & 6.4353 & 5.2157 & 6.3294 & 6.1882 & 5.8588 & 5.3373 & 3.7569 & 3.9412 \\
Median & 7 & 5 & 7 & 7 & 6 & 6 & 4 & 4 \\
Modus & 7 & 5 & 7 & 7 & 6 & 6 & 4 & 4 \\
St. deviation & 1.0587 & 1.4102 & 1.058 & 1.1586 & 1.1854 & 1.3117 & 1.8109 & 1.406 \\
Variance & 1.1208 & 1.9887 & 1.1194 & 1.3424 & 1.4052 & 1.7205 & 3.2792 & 1.9768 \\
\hline
\end{tabular}

Table 9 Model of logistic regression - Czech student population (Variables in the Equation))

\begin{tabular}{|c|c|c|c|c|c|c|c|}
\hline & & B & S.E. & Wald & df & Sig. & $\operatorname{Exp}(B)$ \\
\hline$\stackrel{\pi}{\sim}$ & Gmot & 0.681 & 0.094 & 52.015 & 1 & 0 & 1.975 \\
\hline$\dot{\omega}$ & Constant & -2.316 & 0.37 & 39.161 & 1 & 0 & 0.099 \\
\hline \multirow{3}{*}{$\begin{array}{l}\text { సิ } \\
\text { के } \\
\text { ث্ }\end{array}$} & Dmot & 0.357 & 0.161 & 4.937 & 1 & 0.026 & 1.429 \\
\hline & Gmot & 0.612 & 0.097 & 39.578 & 1 & 0 & 1.844 \\
\hline & Constant & -4.297 & 1.007 & 18.23 & 1 & 0 & 0.014 \\
\hline \multirow{4}{*}{$\begin{array}{l}\text { m } \\
\text { के } \\
\dot{d} \\
\dot{\omega}\end{array}$} & Dmot & 0.489 & 0.166 & 8.716 & 1 & 0.003 & 1.63 \\
\hline & Fmot &,- 414 & 0.145 & 8.161 & 1 & 0.004 & 0.661 \\
\hline & Gmot & 0.704 & 0.108 & 42.463 & 1 & 0 & 2.022 \\
\hline & Constant & -3.234 & 1.02 & 10.056 & 1 & 0.002 & 0.039 \\
\hline \multirow{5}{*}{$\begin{array}{l}\text { चु } \\
\text { के } \\
\text { ثे }\end{array}$} & Dmot & 0.518 & 0.171 & 9.208 & 1 & 0.002 & 1.679 \\
\hline & Fmot &,- 418 & 0.147 & 8.101 & 1 & 0.004 & 0.658 \\
\hline & Gmot & 0.685 & 0.109 & 39.577 & 1 & 0 & 1.983 \\
\hline & $\operatorname{sexCz}(1)$ & 0.713 & 0.328 & 4.712 & 1 & 0.03 & 2.039 \\
\hline & Constant & -3.559 & 1.077 & 10.916 & 1 & 0.001 & 0.028 \\
\hline
\end{tabular}

a Variable(s) entered in step 1: gmot.

b Variable(s) entered in step 2: dmot.

${ }^{c}$ Variable(s) entered in step 3: fmot.

$\mathrm{d}$ Variable(s) entered in step 4: sexCZ(1)

A classification table is used to depict the success rate of the model. The table can be used to determine the percentage of correctly classified objects (for the category of explained variable 0 and 1 and in the aggregate). Classification Table 7 shows that the overall success rate of the model is $77 \%$. The model is more successful in estimating a posi-
Table 10 Classification table - Model Success Rate Calculation - Czech Republic

\begin{tabular}{|c|c|c|c|c|c|}
\hline & \multirow{3}{*}{\multicolumn{2}{|c|}{ Observed }} & \multicolumn{3}{|c|}{ Predicted } \\
\hline & & & \multicolumn{2}{|c|}{ Work Abroad } & \multirow{2}{*}{$\begin{array}{c}\text { Percentage } \\
\text { Correct }\end{array}$} \\
\hline & & & 1 & 2 & \\
\hline \multirow{3}{*}{ Step 1} & \multirow{2}{*}{ Work Abroad } & 0 & 76 & 40 & 65.5 \\
\hline & & 1 & 35 & 104 & 74.8 \\
\hline & \multicolumn{2}{|c|}{ Overall Percentage } & & & 70.6 \\
\hline \multirow{3}{*}{ Step 2} & \multirow{2}{*}{ Work Abroad } & 0 & 69 & 47 & 59.5 \\
\hline & & 1 & 26 & 113 & 81.3 \\
\hline & \multicolumn{2}{|c|}{ Overall Percentage } & & & 71.4 \\
\hline \multirow{3}{*}{ Step 3} & \multirow{2}{*}{ Work Abroad } & 0 & 71 & 45 & 61.2 \\
\hline & & 2100 & 27 & 112 & 80.6 \\
\hline & \multicolumn{2}{|c|}{ Overall Percentage } & & & 71.8 \\
\hline \multirow{3}{*}{ Step 4} & \multirow{2}{*}{ Work Abroad } & 0 & 77 & 39 & 66.4 \\
\hline & & 1 & 30 & 109 & 78.4 \\
\hline & \multicolumn{2}{|c|}{ Overall Percentage } & & & 72.9 \\
\hline
\end{tabular}

a The cut value is 0.500

tive attitude to migrating abroad (85.7\%) than in estimating a negative attitude to migrating abroad $(65.7 \%)$.

The fitness of the regression model was tested using the Hosmer-Lemeshow test. P-value of test was 0.186 . The match between empirical values and the model was not rejected. The value of the depen- 


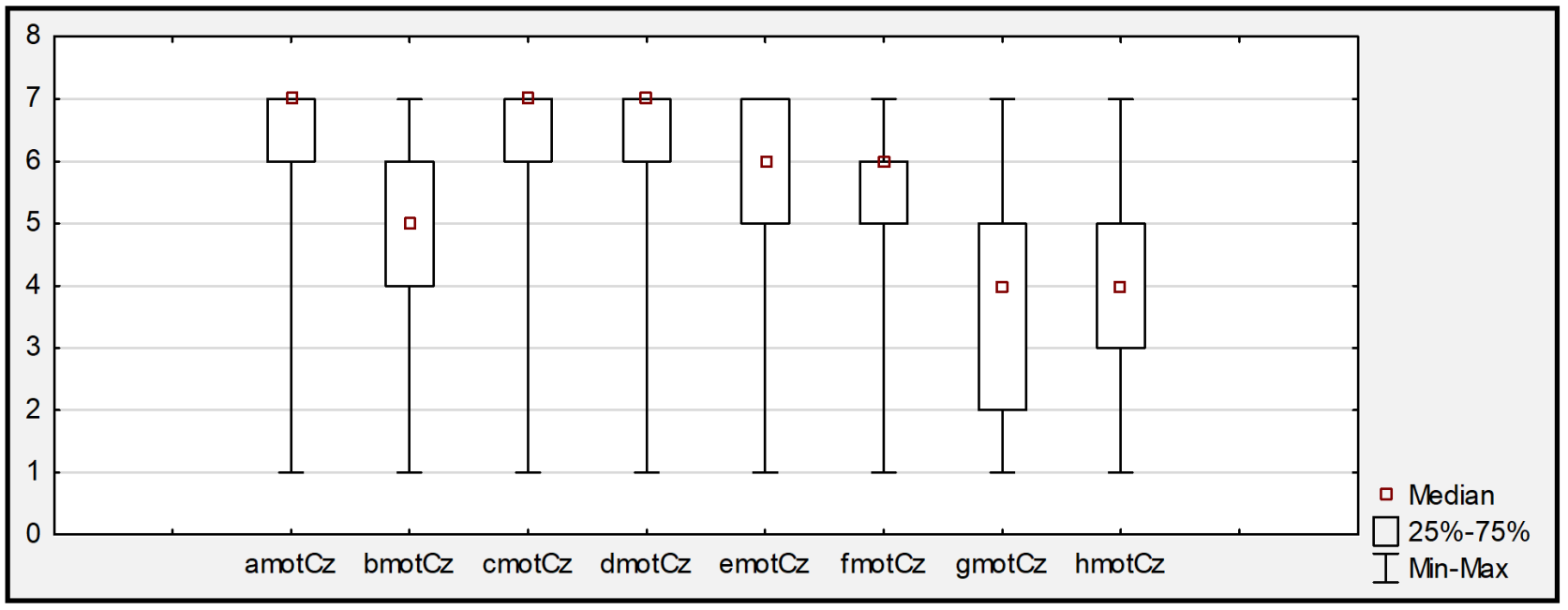

Fig. 2 Labour migration motivation factors - Czech student population Source: authors

dence rate expressed in Nagelkerke's R2 was 0.422 . Thus, it was a weaker moderate dependence.

\subsection{Motivation factors leading to labour mi- gration of Czech student population}

For the Czech student population, the highest arithmetic average was achieved by motivation factors a (Higher wages than in the Czech Republic) and c (Opportunity to improve a foreign language). A greater variability of answers was observed in motivation factor $g$ (I want to live in a different country). The table also shows that the values of arithmetic means of the motives a, c, and d are relatively balanced and are generally higher than the arithmetic averages of motives found in the group of German students (see Table 8).

Fig. 2 shows that $50 \%$ of respondents answered motivation factors a (Higher wages than in the Czech Republic), c (Opportunity to improve a foreign language) and d (Opportunity to acquire foreign experience) using the highest score on the Likert scale (i.e., very strong motivation factor).

To establish significant explanatory variables, logistic forward stepwise regression was chosen. Based on data on the Czech students, motivation factors $\mathrm{g}$ (I want to live in a different country), d (Opportunity to acquire foreign experience), and $\mathrm{f}$ (Better opportunities for career growth than in the Czech Republic) were generated in four steps by the model as explanatory variables; gender was generated as the fourth explanatory variable. The values of coefficients of individual explanatory variables in the model and their significance are given in Table 9.
It follows from the Wald statistics and its p-values in Table 10 that all coefficients in the model significantly differ from zero. The model shows that the biggest impact on whether a student would like to leave to work abroad is based on gender. Men, compared to women, have 2.039 times a greater chance that they will decide to leave to work abroad. Motivation factor g (I want to live in a different country) has the second biggest impact. The likelihood that a student will ever be willing to leave to work abroad increases with each higher score of the Likert scale to 1.983 times. Another motivation factor included in the model is $\mathrm{d}$ (Opportunity to acquire foreign experience). Each increase by one score on the Likert scale towards absolute agreement increases the chance by 1.679 times. With each increase by one score of motivation factor $\mathrm{f}$ (Better opportunities for career growth than in the Czech Republic), the chance decreases by 0.658 times. This indirect influence can be interpreted as follows: the motivation factor was highly evaluated by respondents who do not want to work abroad.

On the basis of this model, the likelihood that a student will ever want to work abroad can be estimated using the coefficients given in the first column of Tab. 10 as follows:

$$
\begin{aligned}
\pi & =\frac{e^{-3.559+0.685 \cdot g m o t}+0.518 \cdot d m o t}{1-e^{-3.559+0.685 \cdot g m o t}+0.518 \cdot d m o t} \\
& =\frac{-0.418 \cdot f m o t+0.713 \cdot \text { sex }}{-0.418 \cdot f m o t+0.713 \cdot \operatorname{sex}}
\end{aligned}
$$


Classification Table 10 shows that the overall success rate of the model is $72.9 \%$. The model is more successful in estimating a positive attitude to migrating abroad $(78.4 \%)$ than in estimating a negative attitude to migrating abroad (66.4\%).

The fitness of the model as a whole was tested using the Hosmer-Lemeshow test. P-value of test was 0.061. A match between empirical and theoretical (model) values was not rejected by the test. The value of dependence rate expressed by Nagelkerke's R2 was 0.395, which shows a weaker dependence.

\section{Discussion}

Many studies indicate that the most frequent reason for people leaving to work abroad are higher wages (Dobrota \& Aceleanu 2006; White 2010; Nowotny 2014). Nowotny (2014) conducted an extensive survey of a population of 5252 Czechs, Slovaks and Hungarians in working age. He concluded that if people expect wages in their home country to rise, the willingness of people to move abroad to work diminishes. On the contrary, the willingness to move abroad to work increases if an individual prefers immediate consumption to future consumption. These findings usually refer to less skilled employees and low-income groups. Bénassy and Brezis (2013) think that a low level of human capital leads to low wages and low wages lead to emigration of skilled human capital. However, Borjas (2006) points out that most immigrants- compared to domestic workers - have a lower income and the incomes of different groups of immigrants differ significantly. Also, Moritz (2011) found that the arrival of foreign workers (i.e., increase in workforce offer) may reduce wages. As an example, he mentions the situation when Czechs came to work in Germany after 1 May 2011, where, subsequently, a drop in relative wage occurred.

However, another finding of this study was that the amount of wage is regarded as important also by people who are not thinking about moving abroad to work. Higher wage is only one of the factors influencing decision-making on labour migration, but it is not a variable explaining emigration. Models generated based on logistic regression clearly showed that other factors are more influential in decision making (e.g., I want to live in a different country or Opportunity to acquire foreign experience), not only in developed economies with high wages (Germany) but also in countries with significantly lower wages (Czech Republic). The fact that mobility is not significantly linked to earnings satisfaction was pointed out by both older studies (Laslett 1971) and more recent studies (Khoo et al. 2007; Dickmann et al. 2008; Al Ariss \& Syed 2011). Evaluation of the influence of economic and non-economic factors on labour migration depends mainly on the country of origin of the migrants. Economic factors are more important for people from less developed countries. For instance, Khattak et al. (2016) state that economic reasons (the opportunity to earn more money) are very strong for migrants from Pakistan but other factors also play a role. As the main push factor, they indicate unemployment, the environment, terrorism, threats, discrimination, and poverty. Among pull factors they list: the opportunity to get a job in a different country, improved life, religious freedom, more education opportunities, level of medical care, entertainment, safety, the opportunity to get married and make friends. Another study conducted in Pakistan reached a similar conclusion, identifying the main reasons for people to emigrate as long-term political instability and fear for their life (Sajjad 2011). Factors motivating people to move abroad to work may be very different and always reflect the situation in the country of origin. In Singapore, Fetzer \& Millan (2015) identified the political situation in a country to be the dominant push factor for the outflow of highly skilled workers. In Portugal, young and skilled employees are "driven" away by high unemployment (Cerdeira et al. 2016).

Within this study, the respondents were students at universities. A declared interest in working abroad may be distorted as values and attitudes change during the life of a person. It is natural that the opinions of a single childless young person (primary following his/her career ambitions) differ from those at a time when he/she has a family. Many studies have proved that such respondents tend more to take into consideration his/her partner and the family (Sperandio \& Devdas 2015).

Other factors influencing labour mobility are, e.g., the personal characteristics of an individual (van Dalen \& Henkens 2012; Remhof et al. 2014), the influence of parents and peers (Dette \& Dalbert 2005) and socio-demographic characteristics such as education, age and gender. Kodrzycki (2001) states that university-educated individuals migrate more often. It was also found that the willingness to move abroad to work decreases with age (Huber \& Nowotny 2013).

Within large countries, there may be significant differences between individual regions. Large differences were noted for university graduates, for example, in Germany, where about half of the gradu- 
ates leave the region in which they studied. About $25 \%$ migrate from Bavaria, while about $40 \%$ from Saxony (Krabel \& Flöther, 2014; Buenstorf et al. 2016). Other studies also refer to an imbalance between German regions in terms of graduate migration (Haussen/Uebelmesser, 2018). Similar results can be found in recent studies from Switzerland. The results show that about half of the students migrate after graduation. Higher tendency to migrate can be observed among students who achieved better academic results (Oggenfuss \& Wolter, 2019).

Another factor influencing the willingness to move abroad to work is gender. For women, an important role when considering leaving for abroad is played by life in a relationship while men are able to separate relationships from work life. Women tend to take fewer risks and when making decisions, they tend more to consider the balance of family and professional life (Myers \& Pringle 2005). However, this finding cannot be generalized because this study found that while gender does not play a role in decision-making on labour migration in German students, with the Czechs, gender has been identified as one of the explanatory variables. Czech men were significantly more interested in working abroad than women.

Last but not least, it may be a factor influencing labour migration and profession. Typical brain drain occurs in healthcare services, concerning both doctors and nurses. Studies on this topic have been created in all countries around the world (Galinskaya \& Levell 2012; Sprinks 2013; Okeke 2013; Lee \& Moon 2013; Santric-Milicevic et al. 2014; Santric-Milicevic et al. 2015; Prasad et al. 2015; Zhou et al. 2016; Dolejš et al. 2016; Shakil 2016; Goździak 2016; Ramos \& Alves 2017; Boström, Öhlander \& Pettersson 2018 and many others). Apart from health professionals, individual countries are also sensitive to the brain drain of scientists from different fields (Grigolo et al. 2010).

It is obvious that it is very difficult to unequivocally determine universal factors with a global effect. Dermendzhieva (2011) states that the costs of migration also play an important role in decisionmaking on migration. Carlson (2013) concluded that geographic migration is not a result of a oneoff choice but the outcome of long-term biographic and social processes and events.

It is believed that temporary labour migration- compared to permanent migration - is economically rather beneficial (both for an individual and his/her country of origin when he/she returns). A more detailed analysis of permanent vs. temporary migration has been brought for example by Ha et al. (2016). From the psychological point of view, temporary migration causes many negative consequences, such as separation from the family if only one of a couple leaves for abroad. If a whole family leaves for abroad, social contacts are disrupted both with friend and grandparents, etc. Many authors refer to negative consequences of a psychological and social nature (Tomsa 2010; Drăgoi 2010; Smeekens et al. 2012; Kačinienè \& Pugevičius 2013; Robila 2014). Within this study, the respondents were students at universities who do not have family and it is highly likely that they do not consider these factors at the moment.

\section{Conclusions}

The outflow of skilled workforce abroad represents significant economic and social losses. This paper focused on brain drain in two neighbouring countries in Central Europe, Germany and the Czech Republic. The objective of the paper was to establish the attitudes of German and Czech university students towards labour migration. It was found that German students declare a greater interest in working abroad, however, the difference is not statistically significant. Other findings are statistically significant. As far as labour migration is concerned, German students think about temporary migration rather than permanent, which is more often mentioned by Czech students. This finding is more positive for Germany as temporary migration brings more economic benefits both for the country and for the individual returning to their home country.

In the case of leaving for abroad, in most cases, German students would like to work in the United Kingdom and the USA, while Czech students most often indicated Germany, the United Kingdom and the USA.

Another objective was to find out what motivation factors are important for students. Half of the German students evaluated the following factors as the most important: "higher wages than in Germany", "opportunity to learn/improve a foreign language" and "opportunity to acquire foreign experience". These factors achieved the highest arithmetic averages. It was an interesting match as half of the Czech students considered the same factors to be most important.

However, the influence of a motivation factor on decision-making on labour migration cannot be deduced from the arithmetic average value. To establish this impact, logistic regression was chosen. All studied motivation factors and the dichotomous variable of gender were included in the 
explanatory variables. To establish significant explanatory variables, logistic forward stepwise regression was chosen. With the German students, two explanatory variables were identified, i.e., "I want to live in a different country" and "opportunity to acquire foreign experience". The model created on the basis of the data of the Czech students contains four explanatory variables. The first two are the same as with the German students. There is also an explanatory variable "better opportunities for career growth than in the Czech Republic" while the fourth explanatory variable is gender. However, the explanatory variable "better opportunities for career growth than in the Czech Republic" returns negative values, which means that each increase by one score on the Likert scale towards absolute agreement decreases the chance that a student will make a decision to leave to work abroad by 0.658 times. A surprising finding occurring in both models was zero occurrence of the motivation factor "higher wages" as an explanatory variable. This does not mean that wages are not important, but it is not a factor having a crucial influence on decision-making on labour migration. The total success rate of the German model is $77 \%$, while it is $72.9 \%$ in the Czech model. In both cases, the model is more successful in estimating a positive attitude to migrating abroad than in estimating a negative attitude to migrating abroad.

Based on the results obtained, national governments should pay particular attention to two important variables, namely "I want to live in another country" and "the opportunity to gain international experience". It is obvious that the new generation has different expectations in this area than the current environment offers. It is necessary to examine these expectations in more detail and then set new programs or measures that will reflect these generational specifics.

\section{Acknowledgement}

This research was supported by the Jan Evangelista Purkyně University in Ústí nad Labem, Czech Republic [grant number UJEP-SGS-2019-45-009-2].

\section{References}

Ailenei D, Badea L, Dima C (2015) The Economic Effects of Emigration of Young Highly Educated Romanians. USV Annals of Economics \& Public Administration 15(1): 7-19.

Al Ariss A, Syed J (2011) Capital Mobilization of Skilled Migrants: A Relational Perspective. British Journal of Management 22(2): 286-304.

Bălan M, Olteanu C (2017) Brain Drain in the Globalization Era: The Case of Romania. Annals of "Constantin Brancusi" University of Targu-Jiu. Economy Series 3: 26-35.

Benassy JP, Brezis ES (2013) Brain Drain and Development Traps. Journal of Development Economics 102: 15-22.

Bielewska A, Jaskułowski K (2017) Place Belonging in a Mobile World: A Case Study of Migrant Professional. Czech Sociological Review 53(3): 343-367.

Boncea I (2015) Turning Brain Drain into Brain Gain: Evidence from Romania's Medical Sector. Procedia Economics and Finance 20: 80-87.

Borjas GJ (2006) Making it in America: Social Mobility in the Immigrant Population. Future of Children 16(2): 55-71.

Boström KW, Öhlander M, Pettersson H (2018) Temporary International Mobility, Family Timing, Dual Career and Family Democracy: A Case of Swedish Medical Professional. Migration Letters 15(1): 99-111.

Buenstorf G, Geissler M, Krabel S (2016) Locations of labor market entry by German university graduates: is (regional) beauty in the eye of the beholder? Review of Regional Research 36(1): 29-49.

Busch O, Weigert B (2010) Where Have All the Graduates Gone? Internal Cross-state Migration of Graduates in Germany 1984 2004. The Annals of Regional Science: An International Journal of Urban, Regional and Environmental Research and Policy: Official Journal of the Western Regional Science Association 44(3): 559-572.

Cai Q (2000) Tentative Analysis of the Various Mechanisms for Attracting People Who Have Gone Abroad for Studies to Come Back and Work in China. Chinese Education \& Society 33(5): 46-56.

Carlson S (2013) Becoming a Mobile Student - a Processual Perspective on German Degree Student Mobility. Population Space \& Place 19(2): 168-180.

Cerdeira L, Machado-Taylor M, de L Cabrito, Patrocínio T, Brites R, Gomes R \& Ganga R (2016) Brain Drain and the Disenchantment of Being a Higher Education Student in Portugal. Journal of Higher Education Policy \& Management 38(1): 68-77.

Dermendzhieva Z (2011) Emigration from the South Caucasus: Who Goes Abroad and What Are the Economic Implications? Post-Communist Economies 23(3): 377-398.

Dette D, Dalbert C (2005) Moving for Their First Job or Staying Put? Predictors of High School Students' Attitudes Toward Geographic Mobility. Journal of Applied Social Psychology 35(8): 1719-1736.

Dickmann M, Doherty N, Mills T, Brewster C (2008) Why Do They Go? Individual and Corporate Perspectives on the Factors Influencing the Decision to Accept an International Assignment. International Journal of Human Resource Management 19(4): 731-751.

Dobrota N, Aceleanu M (2006) New Optics in Analysis and Work Estimation of Abroad Romanian Citizen. Theoretical and Applied Economics 9(504): 9-20. 


\section{sciendo}

Dolejs M, Glorius B, Hruska V (2016) Motives and Barriers of Migration to Saxony: The Case of Migrating Health Professionals from Czechia. Geoscape 10(2): 62-77.

Drăgoi AG (2010) Prevention and Reduction of Factors that Determine Risk Behaviour in Children Whose Parents Are Gone Abroad to Work or Orphans with Parents. Petroleum - Gas University of Ploiesti Bulletin, Educational Sciences Series 62(2): 185-188.

Faggian A, Mccann P, Sheppard S (2007) Human Capital, Higher Education and Graduate Migration: An Analysis of Scottish and Welsh Students. Urban Studies 44(13): 2511-2528.

Fetzer JS, Millan B A (2015) The Causes of Emigration from Singapore: How Much Is Still Political? Critical Asian Studies 47(3): 462-476.

Friberg JH (2012) The Stages of Migration. From Going Abroad to Settling Down: Post-accession Polish Migrant Workers in Norway. Journal of Ethnic \& Migration Studies 38(10): 1589-1605.

Galinskaya E, Levell NJ (2012) Too Far, Too Long, Too Few: Workforce Planning in Dermatology. Clinical \& Experimental Dermatology 37(8): 913-914.

Goździak E (2016) Biała Emigracja: Variegated Mobility of Polish Care Workers. Social Identities 22(1): 26-43.

Grabowski I (2005) Changes in the International Mobility of Labour: Job Migration of Polish Nationals to Ireland. Irish Journal of Sociology 14(1): 27-44.

Grigolo M, Lietaert M, Marimon R (2010) Shifting from Academic 'Brain Drain' to 'Brain Gain' in Europe. European Political Science 9(1): 118-130.

Ha W, Yi J \& Zhang J (2016) Brain Drain, Brain Gain, and Economic Growth in China. China Economic Review 38: 322-337.

Haller A (2017) Alter-Globalism and Development in Migration Conditions. The Case of an East European Country. CrossCultural Management Journal 19(2): 95-103.

Haussen T, Uebelmesser S (2018) No Place Like Home? Graduate Migration in Germany. Growth \& Change 49(3): 442-472.

Huber P, Nowotny K (2013). Moving Across Borders: Who Is Willing to Migrate or to Commute? Regional Studies 47(9): 1462-1481.

Hussain SM (2015) Reversing the Brain Drain: Is It Beneficial? World Development 67: 310-322.

Illiashenko SM, Adamets T (2017) Modern Condition of Labor Migration from Ukraine to the EU and the Prospects for Its Regulation. Economic Processes Management 5(2): 1-9.

Ionescu L (2015) Emigration from Eastern Europe with a Focus on Brain Drain. Journal of Social \& Economic Statistics 4(2): $54-74$.

Józsa I, Vinogradov S A (2017) Main Motivation Factors of Hungarian Labor-migration in the European Union. Management 31(2): 47-52.

Kačinienė I, Pugevičius A (2013) Family with Parents Abroad in the Context of Province. Proceedings of the International Scientific Conference: Rural Development 6: 168-173.

Kaplan S, Grünwald L, Hirte G (2016) The Effect of Social Networks and Norms on the Inter-regional Migration Intentions of Knowledge-workers: The Case of Saxony, Germany. Cities 55: 61-69.

Khattak Z K, Khattak N R, \& Khattak M K (2016) Chasing Employment Globally: Determinants of International Labour Migration in Khyber Pakhtunkhwa, Pakistan. Gomal University Journal of Research 32(1): 53-64.
Khoo SE, McDonald P, Voight-Graf C, Hugo G (2007) A Global Labor Market: Factors Motivating the Sponsorship and Temporary Migration of Skilled Workers to Australia. The International Migration Review 41(2): 480-510.

Kodrzycki YK (2001) Migration of Recent College Graduates: Evidence from the National Longitudinal Survey of Youth. New England Economic Review 1: 13-34.

Krabel S, Flöther C (2014) Here Today, Gone Tomorrow? Regional Labour Mobility of German University Graduates. Regional Studies 48(10): 1609-1627.

Labrianidis L, Vogiatzis N (2013) Highly Skilled Migration: What Differentiates the 'Brains' Who are Drained from Those Who Return in the Case of Greece? Population Space \& Place 19(5): $472-486$.

Lados G (2013) The Impact and Importance of Return Migration in East Central Europe. Forum Geografic 12(2): 132-137.

Lapshyna I (2012) Transformational Changes and Challenges for Human Capital Development in the Context of Ukrainian Labour Migration. Economics \& Sociology 5(1): 111-124.

Laslett B (1971) Mobility and Work Satisfaction: A Discussion of the Use and Interpretation of Mobility Models. American Journal of Sociology 77(1): 19-35.

Lee E, Moon M (2013) Korean Nursing Students' Intention to Migrate Abroad. Nurse Education Today 33(12): 1517-1522.

Marx M, Singh J, Fleming L (2015) Regional Disadvantage? Employee Non-compete Agreements and Brain Drain. Research Policy 44(2): 394-404.

Meeus B (2013) Welfare Through Migrant Work: What if the Romanian 'Safety Valve' Closes? Journal of Southeast European \& Black Sea Studies 13(2): 175-194.

Mirzobobo Y (2017) Determinants of Labor Migration Flows to Russia: Evidence from Tajikistan. Economics \& Sociology 10(3): 72-80.

Moritz M (2011) The Impact of Czech Commuters on the German Labour Market. Prague Economic Papers 20(1): 40-58.

Muthanna A, Guoyuan S (2018) Brain Drain in Higher Education: Critical Voices on Teacher Education in Yemen. London Review of Education 16(2): 296-307.

Myers B, Pringle J K (2005) Self-initiated Foreign Experience as Accelerated Development: Influences of Gender. Journal of World Business 40(4): 421-431.

Nowotny K (2014) Cross-border Commuting and Migration Intentions: The Roles of Risk Aversion and Time Preference. Contemporary Economics 8(2): 137-156.

Oggenfuss C, Wolter S C (2019) Are they coming back? The mobility of university graduates in Switzerland. Review of Regional Research 39(2): 189-208.

Okeke EN (2013) Brain Drain: Do Economic Conditions "Push" Doctors out of Developing Countries? Social Science \& Medicine 98: 169-178.

Panzaru C, Reisz RD (2017) Brain Drain Migration from Romanian Academia. The End of a Mirage. European Review of Applied Sociology 10(14), 34-48.

Petroff A (2016) Reversing the Brain Drain: Evidence from a Romanian Brain Networking Organization. International Migration 54(5): 122-135.

Prasad S B, Amatya A, Sapkota B P (2015) What Factors Influence the Choice of Urban or Rural Location for Future Practice 


\section{S sciendo}

of Nepalese Medical Students? A Cross-sectional Descriptive Study. Human Resources for Health 13(1): 1-9.

Ramos P, Alves H (2017) Migration Intentions among Portuguese Junior Doctors: Results from a Survey. Health Policy 121(12): 1208-1214.

Reiner M, Radu D (2012) Return Migration: The Experience of Eastern Europe. International Migration 50(6): 109-128.

Remhof S, Gunkel M, Schlaegel C (2014) Goodbye Germany! The Influence of Personality and Cognitive Factors on the Intention to Work Abroad. International Journal of Human Resource Management 25(16): 2319-2343.

Robila M (2014) The Impact of Migration on Children's Psychological and Academic Functioning in the Republic of Moldova. International Migration 52(3): 221-235.

Sajjad N (2011) Causes and Solutions to Intellectual Brain Drain in Pakistan. Dialogue 6(1): 31-55.

Santric-Milicevic MM, Terzic-Supic ZJ, Matejic, BR, Vasic V, Rick etts IC (2014) First- and Fifth-year Medical Students' Intention for Emigration and Practice Abroad: A Case Study of Serbia. Health Policy 118(2): 173-183.

Santric-Milicevic M, Matejic B, Terzic-Supic Z, Vasic V, Babic U, Vukovic V (2015) Determinants of Intention to Work Abroad of College and Specialist Nursing Graduates in Serbia. Nurse Education Today 35(4): 590-596.

Shakil SS (2016) Stemming the Medical Brain Drain: A Personal Perspective on a Global Problem. Einstein Journal of Biology \& Medicine 31: 11-16.

Smeekens C, Stroebe M S, Abakoumkin G (2012) The Impact of Migratory Separation from Parents on the Health of Adolescents in the Philippines. Social Science \& Medicine 75(12): 2250-2257.
Spankova J, Grencikova A, Kordos M (2016) Slovak Labor Migration Abroad. Actual Problems of Economics 183(9): 258-263.

Sperandio J, Devdas L (2015) Staying Close to Home: Women's Life-choices and the Superintendency. Journal of Educational Administration 53(3): 335-353.

Sprinks J (2013) Half of Portuguese Nursing School Graduates Leave to Work Abroad. Nursing Standard 28(12): 14-15.

Tomsa R (2010) Psychological Consequences of Temporary Labor Migration upon Children and Family. Petroleum - Gas University of Ploiesti Bulletin, Educational Sciences Series 62(2): 206-212.

Van Dalen HP, Henkens K (2012) Explaining Low International Labour Mobility: The Role of Networks, Personality, and Perceived Labour Market Opportunities. Population Space \& Place 18(1): 31-44.

Vavreckova J, Fischlova D, Janata Z (2002) Migration Potential of the Border Zone of the Czech Republic with Germany. Research Institute for Labour and Social Affairs. Available at: <http://www.vupsv.cz/index.php?p=people publications\&rok $=$ vse\&klasif $=$ vse\&kateg $=$ vse\&oddeleni $=$ vse $\&$ citace $=\&$ pracovnik $=29 \&$ klasif $=$ vse $\&$ site $=$ de fault\&limit $=60 \&$ projekt $=$ vse $>$

Von Proff S, Duschl M, Brenner T (2017). Motives behind the Mobility of University Graduates-A study of Three German Universities. Review of Regional Research 37(1): 39-58.

White A (2010) Young People and Migration from Contemporary Poland. Journal of Youth Studies 13(5): 565-580.

Zhatkanbaeva A, Zhatkanbaeva J, Zhatkanbaev E (2012) The Impact of Globalization on "Brain Drain" in Developing Countries. Procedia - Social and Behavioral Sciences 47: 1490-1494.

Zhou Y, Roscigno C, Sun Q (2016) Why Do China-educated Nurses Emigrate? A Qualitative Exploration. International Journal of Nursing Studies 53: 163-172. 